\title{
UNROOFED CAVES AND RECOGNISING THEM IN KARST RELIEF \\ (DISCOVERIES DURING MOTORWAY CONSTRUCTION AT KOZINA, SOUTH SLOVENIA)
}

\author{
JAME BREZ STROPA IN NJIHOVO RAZPOZNAVANJE \\ NA KRAŠKEM POVRŠJU \\ (ODKRITE PRI GRADNJI AVTOCEST PRI KOZINI, \\ JUŽNA SLOVENIJA)
}

MARTIN KNEZ ${ }^{1} \&$ TADEJ SLABE ${ }^{2}$

${ }^{1,2}$ Karst research institute ZRC SAZU, Titov trg 2, SI-6230 POSTOJNA, SLOVENIA 
Martin Knez \& Tadej Slabe: Jame brez stropa in njihovo razpoznavanje na kraškem površju (odkrite pri gradnji avtocest pri Kozini, južna Slovenija)

Jame brez stropa so bile stare jame, ki so zaradi znižanja kraškega površja razkrite. Posebno pozornost so nam na to pomembno, tudi površinsko kraško obliko osredotočila zemeljska dela pri gradnji avtocest na Krasu. Ključne besede: krasoslovje, gradnja avtocest, jame brez stropa, Kras, Slovenija.

\section{Abstract}

UDC: 551.44:625.7/.8(497.4 Kozina)

Martin Knez \& Tadej Slabe: Unroofed caves and recognising them in karst relief (discoveries during motorway construction at Kozina, South Slovenia)

Unroofed caves are old caves which have appeared due to the lowering of karst relief. Groundwork for motorway construction on Kras has brought our attention to this important surface form of karst relief.

Key words: karstology, motorway construction, unroofed caves, Kras, Slovenia. 


\section{INTRODUCTION}

Unroofed caves are old caves which have appeared due to the lowering of the karst surface. The caves are filled and preserved by predominantly fine-grained sediment. Flowstone and rock boundaries are frequently preserved in the caves.

Excavation for motorway construction on Kras has brought to our attention this important surface form of karst relief (Knez \& Šebela 1994; Šebela \& Mihevc 1995; Kogovšek \& Slabe \& Šebela 1997; Mihevc \& Zupan Hajna 1996; Slabe 1996, 1997a, 1997b, 1998) and has revealed numerous occurrences of unroofed caves in karst relief. We also defined the characteristic forms of unroofed caves in karst relief (Mihevc \& Slabe \& Šebela 1998).

Old caves and shafts open up during motorway construction because of the fluctuation of the karst relief (Kranjc 1997). Old caves are empty or filled with sediment. They formed as part of a cave network while the aquifer was still dammed up to a high level by impermeable rock, causing the underground water table level within to be high. Due to karst processes, the water table level in the aquifer declined and at present is at 200 metres or more below the surface, causing the karst relief to lower.

Unroofed caves may therefore be observed as particular surface karst forms partially transformed by surface processes and are an important element of the epikarst.

Characteristic forms of unroofed caves were observed during preparation for the construction of the motorway at Kozina. Single passages and larger cave networks on horizontal or inclined karst reliefs were discovered.

\section{CAVES DISCOVERED DURING MOTORWAY CONSTRUCTION}

We discovered 56 caves in 6 kilometres on a section of the motorway course between Kozina and Divača. Prevalent are old caves through which water flowed during the transformation of this part of the aquifer from the phreatic into the epiphreatic zone. Three caves were empty, while the rest were filled with fine-grained flysch sediment, pebbles and gravel. The passage diameters ranged up to five metres. The greater part of the old caves were unroofed caves, caused by the lowering of the karst relief. The largest cave network, located at the beginning of the motorway course, was composed of empty passages; one of these was discovered before excavation had been carried out, and the passages were filled with sediment and had a more or less thin ceiling, or were without ceilings. Vertical shafts through which water from the permeable surface percolates were mainly discovered at the bottom of dolines beneath the soil and sediment, but their openings were small and did not allow access.

\section{UNROOFED CAVES AND KARST RELIEF}

Karst relief surrounding the course of the motorway between Kozina and Klanec is distinct in its variegated geologic structure. The road more or less traverses the different lithological and stratigraphical belts of Cretaceous and Paleogene carbonates and Eocene non-carbonates.

In the north-to-south direction at Kozina we found Turonian and Senonian Cretaceous limestones 
followed by beds of Liburnian formation. Among them in the lower part are Cretaceous Vreme beds followed by Palaeocene Kozina beds, Thanetian milliolid limestone and Eocene alveolinid, nummulitid and alveolinid-nummulitid limestones. The motorway crosses a narrow impermeable belt of flysch rocks (marlstone with crustaceans) for the first time to the west of Klanec. After less than 100 metres its course returns onto alveolinid-nummulitid limestone. The final section of the course does not cross karst landscape, as there marlstone with crustaceans and sandstones (flysh) are exposed.

The surface karst morphology and morphogenesis is most likely the reflection of the lithostratigraphic foundation in this part of the karst. Karst relief is generally flat on the southern section of the course, where Paleogene limestones prevail. It is only slightly wavy and without sharp karst forms indicating surface erosion. By contrast, karst relief on the northern part of the course, north and east of Kozina, has intensively eroded the lower Cretaceous rock surface with

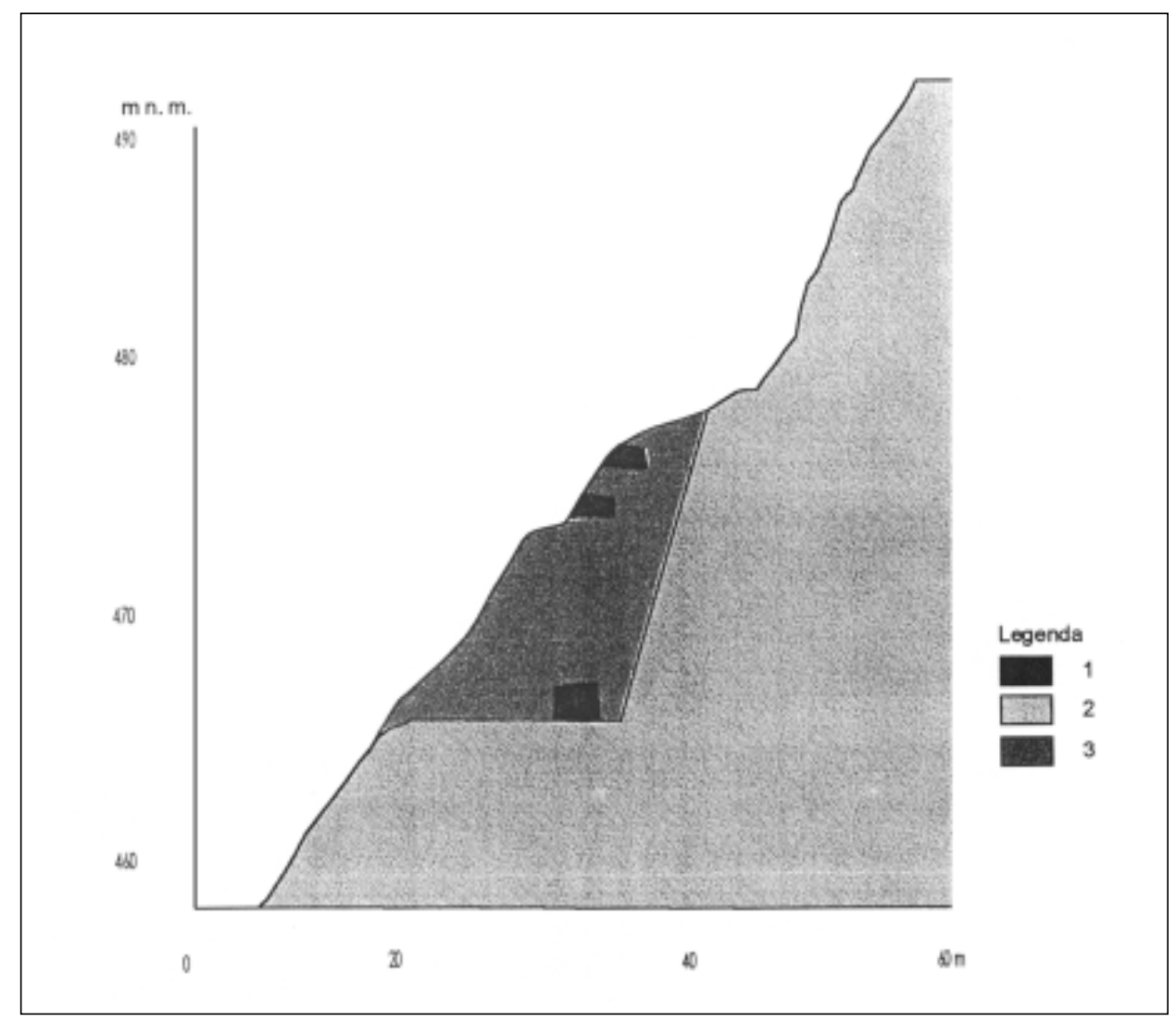

Fig. 1: Caves filled with flowstone and sediment.

1. road cut, 2. paleogene limestone, 3. caves filled with sediment and flowstone.

Sl. 1: Jame zapolnjene s sigo in naplavino.

1. cestni usek, 2. paleogenski apnenec, 3. jame zapolnjene z naplavino in sigo. 
numerous karren and various surface depression.

During the motorway planning stage we defined the depressions that cut through the slopes of the dolines, then continued away from them for several tens of metres as unroofed passage. Road construction confirmed most of these suppositions.

A narrow and shallow depression was found in the slope of a large doline behind a gas station at Kozina; we knew of its location from observing it in the field as well as from the map. Excavation revealed fine-grained sediment filling the cave. Part of the passage was also uncovered at the boundary of the bottom of the doline; on the opposite slope a passage was cross-sectioned. Both were filled with fine-grained sediment. The dolines seem to have developed in the middle of a cave network.

On the relatively steep hillside overlooking Klanec, the beginning of a horizontal passage filled with fine-grained sediment appeared on the surface as a small half-doline (Fig. 1). Excavation to dig a passage revealed a higher and a lower lying passage as part of a cave network.

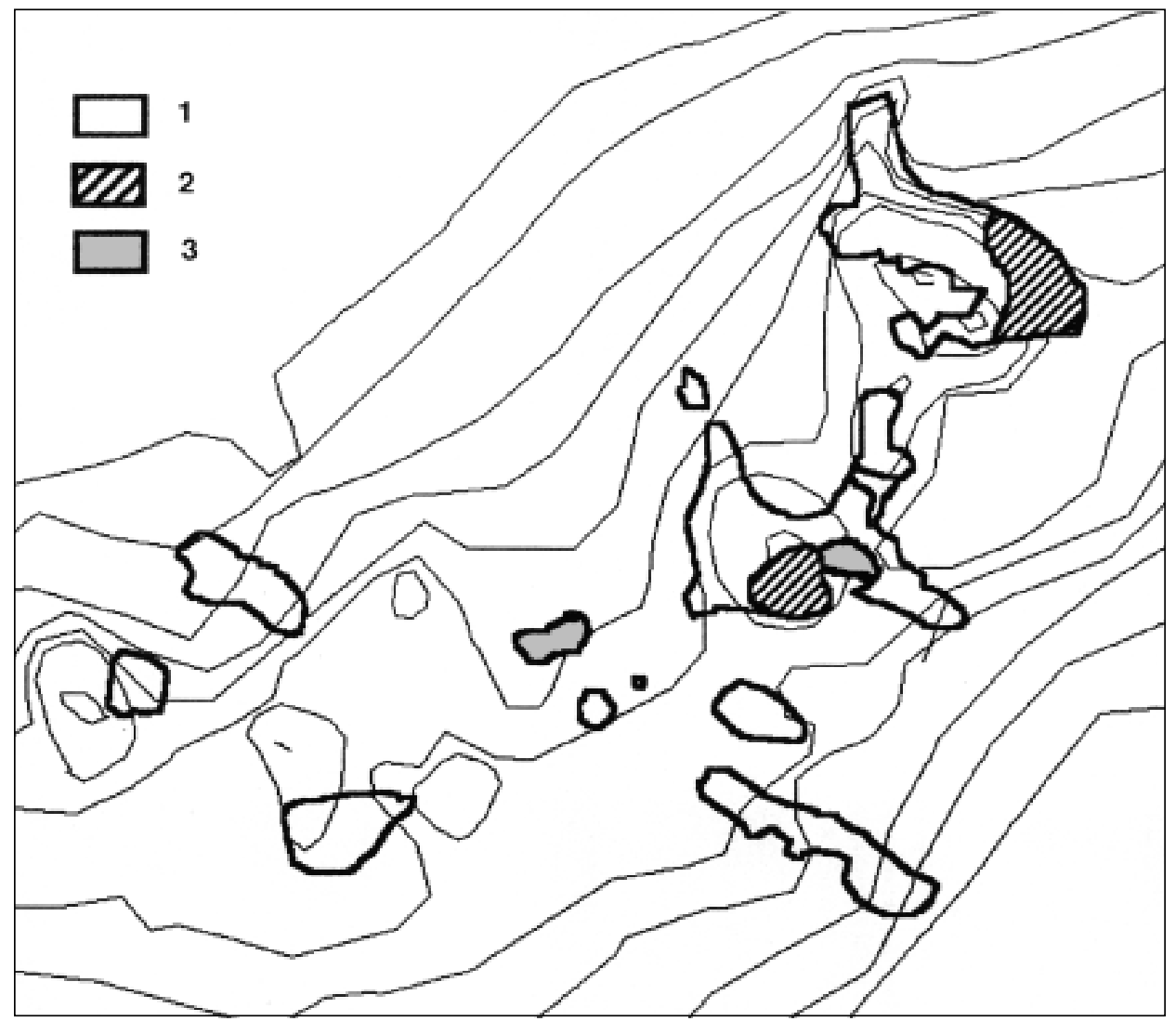

Fig. 2: Unroofed caves and dolines.

1. unroofed caves, 2. dolines, 3. flowstone.

Sl. 2: Jame brez stropa in vrtače.

1. jame brez stropa, 2. vrtači, 3. siga. 


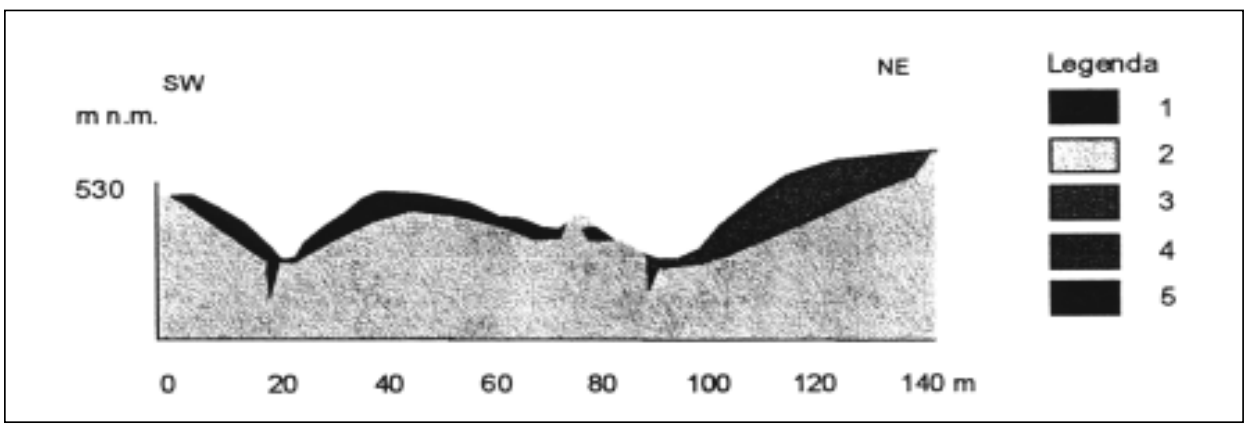

Fig. 3: Cross-section through unroofed caves and dolines with shafts at their bottom. Sl. 3: Prečni prerez čez jame brez stropa in vrtače, ki imajo na dnu brezna.

The largest cave network was uncovered at the beginning of the new section of the route and appeared on the surface as a network of more or less distinct depressions (Fig. 2, Fig. 3) that were more discernible on the slope of the doline, as a connection among them, and as smaller, relatively shallow dolines. The cave network was, besides the parts without ceilings (Fig. 4), composed of a small hollow passage - its existence was known before excavation revealed it - and of passage with ceilings (Fig. 5). Most of the cave was therefore filled with fine-grained sediment. The bottom of the south-western part was almost fully covered with flowstone, stalactites and stalagmites. The flowstone was also covered with fine-grained sediment. Sharp-edged debris covered the surface or filled caves in some locations; frequently it was found among old flow sediments or filling the hollow below shelves in the beginnings of passages. The debris had formed by the rock surface breaking up during the cold Pleistocene epoch. The bottoms of the larger dolines (Fig. 2, Fig. 3) that formed at the edge of an old cave network were covered with layers of brown and red soil a few metres deep. Rock formations located on their edges indicate distinct downward flow of water. Entrances into narrow vertical shafts were also located on the bottoms. Unroofed caves develop into more distinct depressions if the flow of water is able to transport sediment from the surface, which is frequently enabled by the vicinity of a doline.

On a section of the route between Kozina and Klanec the dolines are positioned in a line. We found pieces of flowstone and sediment at the bottom of these dolines. At the edge of a doline next to a belt of flowstone, we dug into a passage with a diameter of over five metres. It was filled with sharp-edged gravel, stalactites and stalagmites. During drilling we also found flowstone in one of the depressions cut into the slope of one of the dolines.

Flowstone was found at many locations on the route. The flowstone discovered on the rock surface following the removal of soil layers, was one of the first "warnings" to observe further digging. We expected to find other sediment in the vicinity, vertically and laterally. In this environment we most frequently discovered cave sediment.

In the northern part of the route, on Cretaceous rock, we discovered the largest heaps of flowstone in terms of surface and thickness. After it was dug out, it was mostly revealed as variously bedded flowstone. Stalactites and stalagmites were hardly present, as they were probably removed together with the sediment or had been crushed and removed earlier. Flowstone in this area is mainly orangebrown in colour, with much less frequent occurrence of white, meat-red and grey-yellow coloured 
M. Knez \& T. Slabe: Unroofed caves and recognising them in karst relief (discoveries during motorway construction...

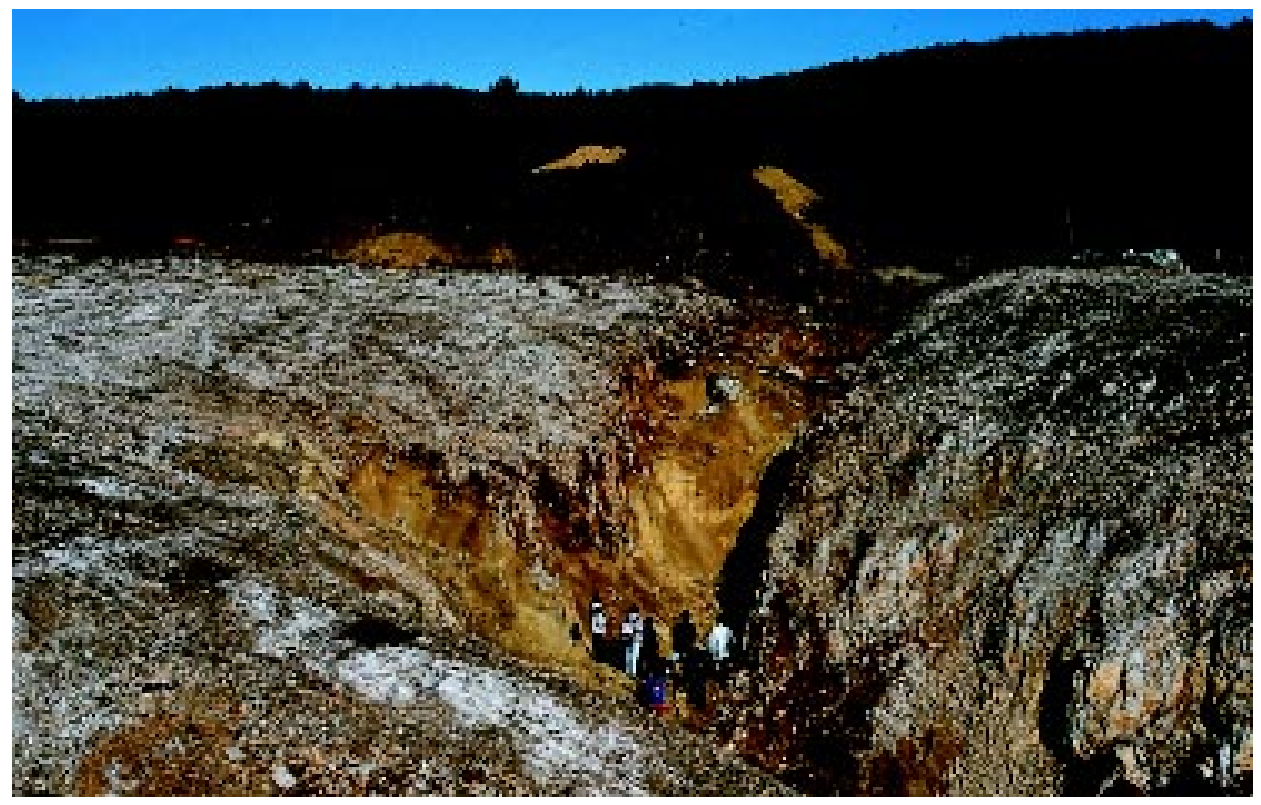

Fig. 4: Unroofed cave.

Sl. 4: Jama brez stropa.

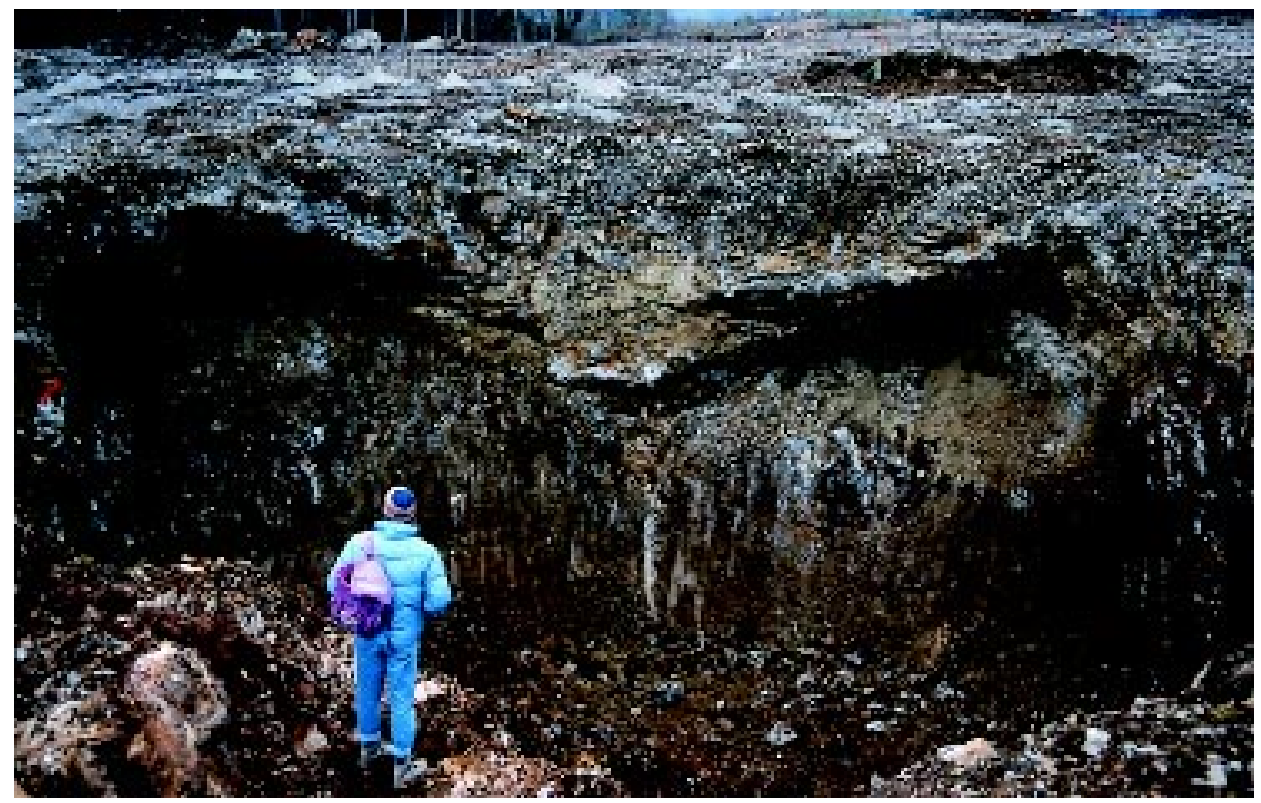

Fig. 5: Cave filled by fine-grained sediment and gravel.

Sl. 5: Jama, ki je zapolnjena z drobnozrnato naplavino in gruščem. 
flowstone. The flowstone alters a great deal in short distances in terms of morphology, colour and state of preservation. Despite this, the flowstone is relatively well preserved as the process of weathering has not yet reached it due to good protection from the surface effects. Most frequently found were column-shaped calcite crystals up to a few centimetres in size, in rare cases over 10 centimetres.

We discovered completely black flowstone of smaller dimensions on the P11 profile (approach Kozina road); this was partially weathered and non-homogenous. It contained a large amount of non-carbonate insertions. A large amount of yellow-grey cave sediment was also contained in a larger flowstone deposit near the $\mathrm{P} 335$ profile. The basic structure of the flowstone was not weathered. Cave sediment later filled the cavities in the otherwise very porous flowstone.

North of the motel at Kozina, still in the northern section of the route, an extremely homogenous and compact bed of orange-brown flowstone was found by drilling. Based on the presence of a group of active dolines in the area, we correctly presumed that an old cave network appeared in this area.

Flowstone appears in considerably smaller amounts in the middle and southern parts of the route. Individual locations are less frequent, although not to be disregarded. Because of the attention given to locating flowstone on the surface, we were able to describe some underground karst phenomena in a road cutting over 20 metres deep.

Flowstone composition and form are also quite various in the middle and southern parts of the route. We mention only the discovery of a large heap of yellow-white bedded flowstone in alveolinicnummulitic limestone. The flowstone stands out in its colour, the way of crystallisation of the calcite crystals, and its state of preservation. It was discovered only a few metres below the surface, almost on the top of the hill near profile P522.

\section{CONCLUSION}

Unroofed caves are an important karst formation, a part of the karst surface and epikarst, as well as significant evidence of the development of the karst. Their forms are a consequence of the cross-section of lowering karst relief with cave networks. Water from the surface also sweeps away cave sediment, which is why unroofed caves frequently hollow out karst relief. In many cases they are complex karst formations. Dolines develop in the middle of old passages or on their boundaries. In these cases the unroofed caves have forms similar to dolines. A number of them can be connected into a series. Open semicircular forms similar to dolines form when the slope is cut into by an old sediment-filled passage.

There can also be old depressions on flat terrain or located on the slopes of dolines. In most cases there is no rock on them and, in cases where one is unable to find evidence of cave sediment and flowstone, they may be distinguished from the rest of the surface by the vegetation covering them. Besides the lithostratigraphical composition of the epikarst, which is a major influencing factor on surface morphogenesis, the appearance of flowstone on the surface and on rock relief can in many cases indicate the existence of an old (and present) underground morphology.

Unroofed caves become clear and explainable surface karst phenomena through observation of characteristic forms, and ever more familiar forms: oblong depressions and doline-like forms on flat or inclined terrain, series of dolines and flowstone belts. 


\section{REFERENCES}

Knez, M. \& S. Šebela, 1994: Novo odkriti kraški pojavi na trasi avtomobilske ceste pri Divači.Naše jame, 36, 102, Ljubljana.

Kranjc, A. (ed.), 1997: Slovene Classical Karst.- ZRC SAZU, pp 254, Ljubljana.

Kogovšek, J. \& T. Slabe \& S. Šebela, 1997: Motorways in Karst (Slovenia).- Proceedings \& a Fieldtrip excursion guide, $48^{\text {th }}$ higway geology symposium, 49-55.

Mihevc A. \& N. Zupan Hajna, 1996: Clastic sediments from dolines and caves found during the construction of the motorway near Divača, on the Classical karst.- Acta carsologica 25, 169-191, Ljubljana.

Mihevc, A. \& T. Slabe \& S. Šebela, 1998: Denuded caves.- Acta carsologica 27/1, 165-174, Ljubljana.

Slabe, T., 1996: Karst features in the motorway section beetwen Čebulovica and Dane.- Acta carsologica 13, 221-240, Ljubljana.

Slabe, T., 1997a: Karst features discovered during motorway construction in Slovenia.Environmental Geology 32/3, 186-190, Springer-Verlag.

Slabe, T., 1997b: The caves in the motorway Dane-Fernetiči.- Acta carsologica 26/2, 361-372, Ljubljana.

Slabe, T., 1998: Karst features discovered during motorway construction between Divača and Kozina.- Acta carsologica 27/2, 105-113, Ljubljana.

Šebela, S. \& A. Mihevc, 1995: The problems of construction on karst - the examples from Slovenia.In: Beck B.F., Pearson F.M. (eds) Karst geohazards, enginnering and environmental problems in karst terrane. Proceedings of the Fifth Multidisciplinary Conference on Sinkholes and the Engineering and Environmental Impacts on Karst. A.A. Balkema, Rotterdam, The Netherlands, 475-479.

\section{JAME BREZ STROPA IN NJIHOVO RAZPOZNAVANJE NA KRAŠKEM POVRŠJU (ODKRITE PRI GRADNJI AVTOCEST PRI KOZINI, JUŽNA SLOVENIJA)}

\section{Povzetek}

Jame brez stropa so bile stare jame, ki so zaradi znižanja kraškega površja razkrite. Ohranjajo pa jih naplavine, predvsem drobnozrnate, s katerimi so zapolnjene. V njih sta pogosto ohranjena tudi siga in skalni obod.

Posebno pozornost so nam na to pomembno, tudi površinsko kraško obliko osredotočila zemeljska dela pri gradnji avtocest (Knez \& Šebela 1994; Slabe 1996, 1997a, 1997b, 1998; Mihevc \& Zupan 1996; Kogovšek \& Slabe \& Šebela 1997), ki so razkrila številne različice pogostega pojavljanja jam brez stropa na kraškem površju. Izluščili smo tudi značilne oblike jam brez stropa na kraškem površju: posamezne vrtačam podobne oblike, vrtačam podobne oblike, ki so povezane v nize in jarke (Mihevc \& Slabe \& Šebela 1998).

Zaradi nižanja površja Krasa (Kranjc 1997) se pri gradnji avtocest odpirajo stare jame in brezna. Stare jame so prazne ali pa zapolnjene z naplavinami. Nastale so kot del spleta votlin, ko je bil vodonosnik še visoko zajezen $\mathrm{z}$ neprepustnimi kamninami in zato je bila višje tudi gladina 
podzemeljske vode v njem. Zaradi zakrasevanja se je znižala gladina vode v vodonosniku, zdaj 200 in več metrov globoko pod površjem, in znižuje se kraško površje.

Jame brez stropa lahko torej razbiramo tudi kot svojevrstne površinske kraške oblike, deloma so preoblikovane s površinskimi procesi in so pomemben del epikrasa.

Značilne oblike jam brez stropa smo razbrali tudi pri zemeljskih delih ob gradnji avtoceste pri Kozini. Odkriti so bili posamezni rovi in večji jamski spleti na vodoravnem ali nagnjenem kraškem površju.

Jame brez stropa so pomembna kraška oblika, del kraškega površja in epikrasa in pomembna sled razvoja krasa. Njihova oblika je posledica prereza znižujočega kraškega površja z jamskimi spleti. Voda s površja odnaša tudi jamsko naplavino in jame brez stropa so zato pogosto vdolbljene v kraško površje. Večkrat so sestavljene kraške oblike. Sredi starih rovov ali pa na njihovem robu so nastale vrtače. V tem primeru imajo jame brez stropa obliko podobno vrtačam. Več jih je lahko povezanih v nize. Odprte polkrogelne, vrtačam podobne oblike nastajajo, ko pobočje preseka star rov, ki je zapolnjen z naplavinami. Lahko pa so tudi samostojne zajede na ravnem površju ali pa členijo boke vrtač. Na njih največkrat ni skalovja in od ostalega površja se ločijo po rastju, seveda, če na površju ni razbrati tudi jamskih naplavin in sige. Poleg litostratigrafske sestave epikrasa, ki bistveno vpliva na površinsko morfogenezo nam tudi pojavljanje sige na površini lahko nakazuje možnosti nekdanje (pa tudi sedanje) podzemeljske morfologije.

Po značilnih, vse bolj znanih oblikah: zajede, vrtačam podobne oblike na ravnem ali nagnjenem površju in nizi vrtač ter proge sige, postajajo jame brez stropa vse bolj razločljiv in berljiv površinski kraški pojav. 